\title{
Descriptive Analysis of the Concept of Conventional Integrity for Civil Servants: A Theoretical Study
}

Ahmad Safwan Jamaludin, Wan Khairul Aiman Wan Mokhtar, Abdullah Ibrahim, Wan Mohd Khairul Firdaus Wan Khairuldin, Abdul Hanis Embong, Mohd Mustaffami Imas, Asma Afifah Rashid \& Eusoff Amiruddin

To Link this Article: http://dx.doi.org/10.6007/IJARBSS/v11-i12/11862

DOI:10.6007/IJARBSS/v11-i12/11862

Received: 03 October 2021, Revised: 06 November 2021, Accepted: 28 November 2021

Published Online: 11 December 2021

In-Text Citation: (Jamaludin et al., 2021)

To Cite this Article: Jamaludin, A. S., Mokhtar, W. K. A. W., Ibrahim, A., Khairuldin, W. M. K. F. W., Embong, A. H., Imas, M. M., Rashid, A. A., \& Amiruddin, E. (2021). Descriptive Analysis of the Concept of Conventional Integrity for Civil Servants: A Theoretical Study. International Journal of Academic Research in Business and Social Sciences, 11(12), 1052-1059.

\section{Copyright: (c) 2021 The Author(s)}

Published by Human Resource Management Academic Research Society (www.hrmars.com)

This article is published under the Creative Commons Attribution (CC BY 4.0) license. Anyone may reproduce, distribute, translate and create derivative works of this article (for both commercial and non0-commercial purposes), subject to full attribution to the original publication and authors. The full terms of this license may be seen at: http://creativecommons.org/licences/by/4.0/legalcode

Vol. 11, No. 12, 2021, Pg. 1052 - 1059

Full Terms \& Conditions of access and use can be found at http://hrmars.com/index.php/pages/detail/publication-ethics 


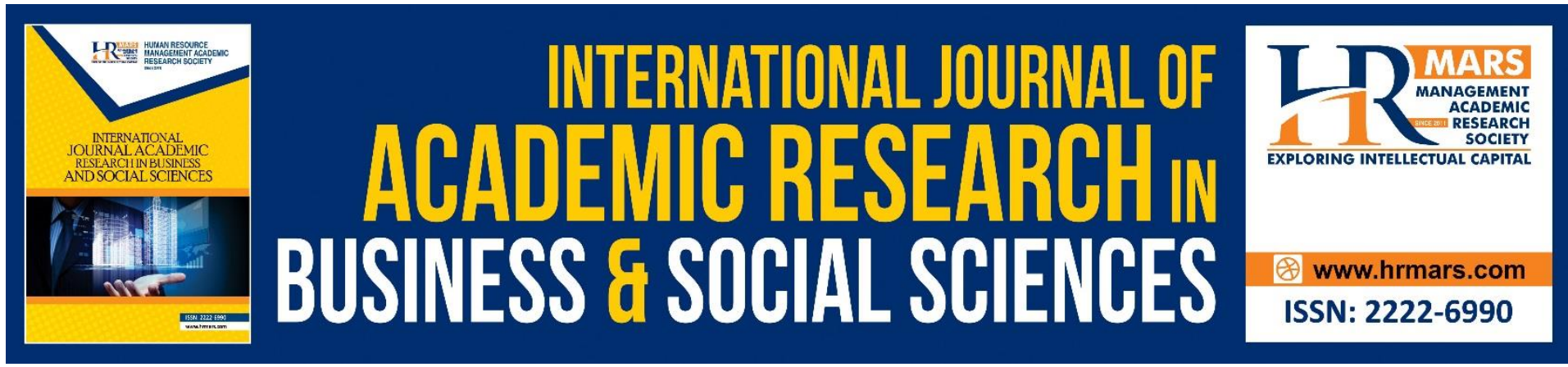

\title{
Descriptive Analysis of the Concept of Conventional Integrity for Civil Servants: A Theoretical Study
}

\author{
Ahmad Safwan Jamaludin, Wan Khairul Aiman Wan Mokhtar, \\ Abdullah Ibrahim, Wan Mohd Khairul Firdaus Wan Khairuldin, \\ Abdul Hanis Embong, Mohd Mustaffami Imas, Asma Afifah \\ Rashid \& Eusoff Amiruddin
}

Universiti Sultan Zainal Abidin (UniSZA), Kampus Gong Badak, 21300 Kuala Nerus,

Terengganu, Malaysia

\begin{abstract}
The implementation of the Government Transformation Program (GTP) 2.0 through the National Key Result Areas (NKRA) on Corruption is one of the government's priorities. However, the performance and integrity of civil servants in Malaysia are still at a problematic level. Issues such as corruption and inefficiency in public service delivery are becoming increasingly serious. Therefore, the question is whether the concept of integrity for existing civil servants is fully effective? What is the concept of integrity that is practiced? Therefore, it becomes a necessity to study this concept of integrity of conventional civil servants. For Muslims and Muslim countries, the model is seen as better if it is sourced and based on true Islam as Malaysia will make the prevention of corruption and integrity as a subject in schools and institutions of higher learning (IPT). Therefore, three objectives were set for this study namely to identify the concept of conventional integrity for civil servants; and analyse the conventional concept of integrity for civil servants based on the Quran and Sunnah. The design of this qualitative study is exploratory research. This study also uses library research methods for data collection. Data were analysed using content analysis method. The results of this study found that the concept of conventional integrity is not very broad compared to the concept of Islamic integrity. This is because, it does not cover the external and internal aspects of human beings. This discussion of the concept of integrity in Islam is more similar to the application of Islamic morality. Unlike the conventional, it does not cover the external and internal elements. The question of morality is not raised as well as different goals and sources
\end{abstract}

Keywords: Conventional Integrity Concept, Civil Servants' Integrity Concept, and Islamic Integrity Concept

\section{Introduction}

Integrity comes from the Latin word "integer", which means comprehensive, perfect, and firm unity (Field \& Fridlund, 2003). Roberts (1994), elaborates on the definition of integrity as the 
union of full commitment to the values held in every speech and action of a person. Roberts's (1994) definition is parallel to Musschenga's (2001), defining integrity as the internal consistency and coherence of a person's beliefs with his or her statements and actions. Integrity is an important concept in ethical reasoning (Field \& Fridlund, 2004). Integrity is closely related to the formation and strengthening of good ethics (Mahathir, 2004). It needs to do the right thing (Musatafar 2004).

The question that arises is, what is the conventional concept of integrity in use today? Is the concept theory comprehensive enough to be applied to Muslims and the Islamic State? So this study was done to identify and analyse the concept.

\section{Research Methodology}

This study uses a qualitative approach. The design used is an exploratory research method. For data collection, this study uses the library research method. The data obtained will be used for content analysis methods for analysis purposes.

\section{Findings and Research Discussion Definition of Integrity}

Integrity can also be defined as a positive quality or characteristic that exists holistically in individuals and organizations. The characteristics and qualities of integrity contain the element of "wholeness", meaning that integrity exists in an integrated and truly comprehensive manner. This characteristic of integrity can be possessed by individuals, organizations and communities. The word integrity can also be understood through some examples of its usage. For example, "integrity of national sovereignty" means a country that has a strong defense so that it is difficult to be threatened by outsiders. "Integrity of the body" means a strong human body in terms of physical and mental, and no disease. "Building integrity" refers to a sturdy building that is difficult to collapse despite natural disasters. "Integrity of an institution" refers to the strength of a good name that is not tarnished despite being thrown with various accusations (Ali, 2009: 48).

Based on the Bilingual Dictionary, the word integrity means honesty, sincerity, sincerity, perfection, and integrity (Aziz, 2009: 92). The meaning of integrity according to Kamus Dewan is honesty, which refers to a state of perfection and integrity or integrity (Kamus Dewan, 2007: 583). According to the National Integrity Plan, integrity means superior quality inherent in and cohesive in individuals and organizations. It is also closely related to ethics and the reflection of ethics in daily actions (Malaysian Institute of Integrity, 2008:18). The definition of integrity also refers to the opposite meaning of corruption. If corruption is defined as the abuse of power entrusted for personal and political purposes, then integrity means the use of public power for purposes officially confirmed and justified by the public (Pope, 2007: 5).

\section{The Concept of Integrity}

According to Shah and Yusoff (2006:41-45), integrity is derived from elements of values, ethics, morals, and culture. Therefore, what is most important in pushing for integrity to be implemented is an approach that encompasses all levels in all sectors and institutions.

Integrity can also be seen through measures to manifest elements of quality in the organization. These elements are related to its mission statement, vision, governance, and 
certain codes of ethics created and practised by each institution, whether it is a voluntary body, corporate, or government department (Mahboob, 2006: 273). This means that integrity is very important and is a key component in ensuring the smooth administration of the government, the private sector, and the general public. The structure of a quality organisation must be neatly arranged, focused, and have clear and reasonable goals. The goals are not in conflict with each other because that would affect integrity. For example, there are institutions that cultivate pure values, while there are others that spread the opposite values. This conflict of interest, if it occurs continuously, will lead to confusion and a crisis of values. Thus, the integrity of individuals, society, and the country is also affected (Malaysian Institute of Integrity, 2010: 13-14).

Integrity is also authority, integrity and overall disposition in terms of personality, morals, speech and manners. This means that integrity is very important because it is a manifestation of the personality and behaviour of the individual in turn reflects the behaviour of the nation. The importance of integrity has something to do with the dignity of the nation. The nation is the human resource to the nation. It is a disgrace to the nation in Malaysia, although its people are high income, have good physical facilities, but its nation practises ugly behaviours and culture such as accepting bribes, disobeying the law, not trustworthy and irresponsible (Mahboob, 2006).

In addition, if viewed in a more specific context, the integrity of the habit will be related to the behaviour or responsibilities that must be practised by an individual in the organisation to which he or she belongs. Integrity is the cornerstone of the achievement of quality work that has been entrusted to an individual or an organization. It also coincides with the integrated and comprehensive characteristics that are organised in an organisation (Rahman, 2005). Integrity can be described through the appreciation and practise of noble values that are evident through the actions taken by an individual (Jamiah et al., 2005). Individual moral responsibilities and commitments, the discipline of employee codes of ethics in organizations, and citizens' adherence to the national legal system (Grant, 2010; Sulaiman, 2006) that are central to these values of integrity are developed in accordance with local community values in a country (Pattison \& Edgar, 2011).

In an effort to improve the quality of national integrity, the Malaysian government has acted to prepare a National Integrity Plan (PIN) (National Institute of Integrity, 2005: 16) which is monitored by the Malaysian Institute of Integrity (INTEGRITI) (National Institute of Integrity, 2006: 3). The main role of the Malaysian Institute of Integrity (INTEGRITI) is to coordinate and monitor the implementation of the PIN. INTEGRITI was registered as an independent body with the status of a Malaysian government guaranteed company under the Companies Act 1965 on 4 March 2005. The establishment of INTEGRITI was announced to the public on 23 April 2004 in conjunction with the launch of PIN. INTEGRITY is governed by a Board of Directors chaired by the Chief Secretary to the Government and also comprised of a number of influential figures in various fields.

This plan has placed the main focus on inculcating and nurturing a culture of ethics and integrity among all levels of Malaysian society. Through this plan, the Malaysian government plans various programs systematically in an effort to cultivate integrity among the community. Although various efforts have been made before, but these efforts have failed 
because they are felt to be inconsistent and incomplete because no planned efforts are implemented continuously and do not cover all sectors, areas or components of society (National Integrity Institute, 2008: 30-31).

Compared to the PIN that has been drafted, it seems that the scope and concept brought is comprehensive because it is monitored and implemented specifically by INTEGRITY which covers all sectors, areas and components of society in providing guidance to every layer of society to cultivate integrity (Malaysian Institute of Integrity, 2008: 30 -31). The researcher is also of the view that the efforts made by the government are very good after the existence of some facts of weakness of integrity among individuals, organisations and civil servants in Malaysia as explained. The National Integrity Plan (PIN) also lays out several aspects of the division of integrity (Mahboob, 2005: 3):

a) Individual Integrity: The harmony between what an individual says and what he or she says; the harmony of his actions with moral, ethical, and legal principles; and the harmony between self-interest and public interest. What the individual does is fast, accurate, and quality. When he acts or behaves in such a way consistently in various ways, he is said to have integrity. When acting otherwise, he is said to lack integrity or weaken his integrity.

b) Organizational Integrity: Refers to organisations that implement codes of ethics, client charters or systems and work processes as well as adherence to best practices. The code of ethics of the organisation is emphasized, repeated and lived by the members of the organisation until it becomes a habit and eventually becomes the culture of the organization.

c) Civil Servants' Integrity: Refers to civil servants who exercise the trust and authority entrusted to them in the public interest. A civil servant must not abuse his power for the benefit of himself, his family, relatives, or kin. When a conflict of interest occurs, it must be resolved by giving priority to the public interest. As such, the servant must be transparent and sincere, and must take responsibility for his boss, the people under him, and others.

\section{Concept of Conventional Integrity}

The word integrity is taken from the Latin word integer, meaning entire, i.e., whole or untouched. It also carries the meaning of unaffected, strong, true, or reliable (Ismail; Ismail \& Badron, 2011: 48). The Latin word also means wholeness, referring to the combination of one's identity in terms of consistent beliefs, speech, and deeds. It didn't change even though there was something trying to influence his beliefs, speech, and actions. Thus, a person is considered to have integrity when he persists and perseveres in maintaining his true values and behaviours even when he is in a situation that may prompt him to change his attitudes and actions (Tullberg, 2012).

According to Bauman (2013:415), the original meaning of the word integrity needs to be referred to its etymological aspect. Integrity comes from the Latin word "integrity," which means wholeness or integration. This suggests that in order to achieve integrity, it needs to be all-encompassing and integrated. In academic discussions, the word is termed as an 
integrated picture of the self (Scherkoske, 2013: 10) and also as a mould of a person integrating various individual personalities towards holistic harmony and wholeness (Cox, La Caze \& Levine, 2013). Although it can also be defined as an individual who is inconsistent between self and commitment, the image of self-integration is excluded due to the absence of conflict, as there is no conflict in commitment, values, and desires without integrity or questions of integrity (Cox, Caze \& Levine, 2003: 19). Thus, integrity is its own integrity and cannot be explained in detail about its implementation.

According to Nillsen (2005:86), there are two meanings of the word integrity. First, it refers to wholeness and perfection, while the second refers to the firmness of moral principles, in particular, straightness, honesty, and sincerity. However, now it refers more to moral principles. According to the New Oxford dictionary (2004:423), integrity means the quality of being honest and having strong moral principles or the quality of being honest and upright or having strong moral principles.

Montefiore and Vines (1999: 9) formulate the latin word, integras which means whole, comprehensive, the harmony as a consistent wholeness or perfection as well as the integration of principles and values. Some view integrity as professional or responsible integrity (taking into account from an environmental point of view): taking professional steps in performing tasks, caring and responsible and taking into account relevant interests (Karssing, 2001/2007: 3).

Integrity requires integration between moral values, where these moral values are consistent with social values. Then, integrity requires a harmonisation between the perpetrator's behaviour with moral values and social values at all times and across a variety of social contexts (Dunn, 2009: 109). Some view that integrity emphasises other specific values of either one or more. For example values such as trusts; honesty; not in favour of the undeserving; concerned with responsibilities (as contained in the rules). This view links integrity with virtue. This means that integrity acts in line with virtues such as wisdom, justice, courage, and simplicity (Becker \& Talsma, 2016; van Tongeren \& Becker, 2009).

In general, Montefiore and Vines (1999: 9) formulate it from the Latin word, integras which means whole, comprehensive, the harmony as a consistent wholeness or perfection as well as the integration of principles and values. Some view integrity as professional or responsible integrity (taking into account from an environmental point of view): taking professional steps in performing tasks, caring and responsible and taking into account relevant interests (Karssing, 2001/2007, p. 3).

In contrast to theories that say that integrity has to do with morality, it has to do with the division of positive and negative values. This theory is divided into two parts. The first says that integrity is a reflection of ethics (Carter, 1996). While the second states that integrity is the parent of a holistic nature, uniting the values that link it to justice. Both of these theories form the beginnings of an explanation of principles and ethics (Lee \& Rosenbloom, 2005; Rosenbloom, 2011). 


\section{Conclusion}

Conventional integrity has its own concept. Integrity exists when it is integrated and truly comprehensive. It covers the definitions, characteristics, qualities, elements, and methods available. In fact, integrity means honesty, sincerity, sincerity, perfection, and wholeness. Moreover, it is also meant by "honesty," which refers to a perfect state of mind and integrity. Integrity is derived from elements of values, ethics, morals, and culture. Integrity can also be seen through measures to manifest elements of quality in the organization. Integrity is also authority, integrity, and overall disposition in terms of personality, morals, speech, and manners. As a result, this conventional concept of integrity is seen as providing an explanation of principles and ethics. Therefore, it differs from the concept of Islamic integrity because of its small scope. It does not cover external and internal elements like morals and dignity, as well as different goals and resources.

\section{Acknowledgement}

This paper is founded on the research project of the Fundamental Research Grant Scheme FRGS/1/2018/SSI03/UNISZA/02/2 (Project No: RR279). Special appreciation is owed to Ministry of Higher Education Malaysia (MOHE) and Universiti Sultan Zainal Abidin (UniSZA) for sponsoring and supporting this research.

\section{Corresponding Author}

Wan Khairul Aiman bin Wan Mokhtar (Ph.D)

Senior Lecturer, Universiti Sultan Zainal Abidin (UniSZA), Kampus Gong Badak, 21300 Kuala Nerus. Tel: +609-6688776. Faks: +609-6687861. Email: wk_aiman@yahoo.com / wkhairulaiman@unisza.edu.my

\section{References}

Ismail, A. R. (2005) Malaysia Cemerlang, Gemilang dan Terbilang: Integriti Jadi Agenda. PEMIKIR.

Dunn, C. P. "Integrity Matters", International Journal of Leadership Studies, volume 5, issue 1 (2009)

Grant S. A. (2010) Maintaining Integrity and Quality Leadership in Law Enforcement Supervision. Florida Department Law Enforcement, Florida.

Manap, J. (2005). "Pemantapan Nilai Integriti Individu sebagai Teras Pembangunan Staf Berkualiti". Seminar Kebangsaan Sumber Manusia, Johor Bahru: Universiti Teknologi Malaysia, 2 \& 3rd February 2005.

Ismail, M. Z., \& Badron, M. S. (2011). Good Governance Adab-Oriented Tadbir in Islam (Kuala Lumpur: IKIM, 2011),

Ali, M. (2005). Etika dan Integriti di Malaysia Isu dan Cabaran. Kuala Lumpur: Ter. Institut Integriti Malaysia.

New Oxford. (2004). Shah Alam: Oxford Fajar Sdn. Bhd.

Roberts, A. B. (1994) Core values in a Quality Air Force. Airpower Journal, Summer 94, 8 (2).

Nillsen, R. "The Concept of Integrity in Teaching and Learning", Journal of University Teaching \& Learning Practice, 2 (3).

Mokhtar, W. K. A. W., Ibrahim, A., \& Embong, A. H. (2018). Al-'Aqīdaț Al-Ṣaḥịnaț as the Essential Element of Worldview of Development Integrity and Accountability. International Journal Of Academic Research In Business And Social Sciences, 8(11), 328-337. 
Ibrahim, A., Mokhtar, W. K. A. W., Ali, S., \& Simin, M. H. A. (2017). Effect of transformational principal leadership style on teachers commitments and school achievement. International Journal of Academic Research in Business and Social Sciences, 7(5), 518527

Widang, I., \& Fridlund, B. (2003) Self-respect, Dignity and Confidence: Conceptions of Integrity Among Male Patients. Journal of Advanced Nursing 42 (1), p47. 